Article

\title{
Towards a Better Understanding of the Removal of Carbamazepine by Ankistrodesmus braunii: Investigation of Some Key Parameters
}

\author{
Tania Yehya ${ }^{1}\left(\mathbb{D}\right.$, Lidia Favier ${ }^{2, *} \mathbb{C}$, Fabrice Audonnet ${ }^{1} \mathbb{D}$, Nidal Fayad ${ }^{1}$, Hajar Bahry ${ }^{1}$, \\ Gabriela Elena Bahrim ${ }^{3, *(1)}$ and Christophe Vial ${ }^{1, *}$ \\ 1 Université Clermont Auvergne, CNRS, SIGMA Clermont, Institut Pascal, F-63000 Clermont-Ferrand, France; \\ taniayehia188@hotmail.com (T.Y.); fabrice.audonnet@uca.fr (F.A.); NidalFayad@hotmail.fr (N.F.); \\ hajarbahry91@gmail.com (H.B.) \\ 2 Univ Rennes, Ecole Nationale Supérieure de Chimie de Rennes, CNRS, ISCR—UMR6226, \\ F-35000 Rennes, France \\ 3 Faculty of Food Science and Engineering, “Dunărea de Jos” University of Galati, Domnească Street No. 111, \\ 800201 Galati, Romania \\ * Correspondence: lidia.favier@ensc-rennes.fr (L.F.); gabriela.bahrim@ugal.ro (G.E.B.); \\ christophe.vial@uca.fr (C.V.); Tel.: +33-233238135 (L.F.); Fax: +33-223238120 (L.F.)
}

Received: 9 October 2020; Accepted: 5 November 2020; Published: 12 November 2020

\begin{abstract}
Nowadays, water pollution by pharmaceuticals is a major issue that needs an urgent solution, as these compounds, even when found at trace or ultra-trace levels, could have harmful effects on organisms. Carbamazepine (CBZ) is a pharmaceutical product that is detected as a micropollutant in many water resources. Different treatment methods were lately employed for the removal of CBZ, which are often cheap but inefficient or efficient but expensive. Yet, there are limited available studies on the elimination of this molecule by algae despite their well-known highly adaptive abilities. In this study, the biological treatment of CBZ was carried out using the green microalgae, Ankistrodesmus braunii (A. braunii), which has been reported to be particularly resistant to $C B Z$ toxicity in the literature. The respective effects of the culture medium, the initial inoculum, and CBZ concentrations were studied on CBZ removal. Lastly, the mechanism of CBZ elimination by $A$. braunii was investigated. The presented data clearly demonstrates that the presence of this molecule did not completely repress $A$. braunii growth or the ability of these algae to remove CBZ; after 60 days of incubation, the highest percentage of CBZ elimination achieved was $87.6 \%$. Elimination was more successful in Bold's basal medium than in proteose peptone medium. Finally, the removal mechanism was also investigated to provide a better understanding of the transformation mechanism of this molecule. It was shown that the main removal mechanism was the bioaccumulation of CBZ by A. braunii cells, but the biotransformation of the initial CBZ into metabolites was also observed.
\end{abstract}

Keywords: carbamazepine; microalgae; micropollutant; phycoremediation; water treatment

\section{Introduction}

Water pollution due to anthropic contaminants or pollutants is an increasing global concern. Ranging from macro- to micro-pollutants, these are caused by different human activities, such as urban and industrial development, the use of chemical fertilizers and pesticides in agriculture, mining activities, and the disposal of pharmaceuticals and personal care products [1-3].

Water contamination by pharmaceuticals has been an environmental issue of concern since the late 1980s [4]. During the 1990s, pharmaceutically active compounds, such as lipid-regulating drugs, analgesics, antibiotics, antiseptics, hormones, and chemotherapy and beta-blocking heart 
drugs, were detected in wastewaters, streams, and ground-water resources across Europe [5]. These molecules can have diverse and adverse effects on organisms and aquatic life. For this reason, the pharmaceutical product discharges from human and veterinary usage have been the object of intensive research for several years [6]. Numerous studies in Europe and North America have shown that carbamazepine (CBZ) is among the most frequently detected pharmaceutical products in the effluents of the municipal wastewater treatment plants and in the river waters [7]. Indeed, this molecule has a very low biodegradability and is considered environmentally persistent and refractory (see detailed information in Table 1).

Table 1. Therapeutic use and physicochemical properties of carbamazepine.

\begin{tabular}{cc}
\hline Carbamazepine & Antiepileptic \\
Therapeutic class & \\
Structure & $17.66^{\mathrm{a}}$ \\
$\mathrm{Molar}^{\mathrm{a}}$ mass $(\mathrm{g} / \mathrm{mol})$ & 2.25 \\
$\mathrm{pK}_{\mathrm{a}}$ at $25^{\circ} \mathrm{C}$ & 510 \\
Boiling point $\left({ }^{\circ} \mathrm{C}\right)$ & $1.08 \times 10^{-10} \mathrm{a}$ \\
Solubility in water at $25^{\circ} \mathrm{C}(\mathrm{mg} / \mathrm{L})$ &
\end{tabular}

CBZ is a human pharmaceutical approved by the United States (US) Food and Drug Administration for treating epileptic seizures and trigeminal neuralgia. It is also used "off-label" to treat bipolar depression, excited psychosis, and mania [9]. CBZ is composed of two benzene rings fused to an azepine group, which in turn is connected to an amide group [10]. Its doses commonly range from 100 to $2000 \mathrm{mg}$ per day [11,12], which is reflected by an annual consumed quantity of CBZ in the world of about 1014 tons [13]. Post-administration, approximately $72 \%$ of oral CBZ can be absorbed, metabolized, and excreted in urine, whereas $28 \%$ is unchanged and is discharged into waters through feces [14]. Consequently, CBZ and its metabolites: trans-10,11-dihydro-10,11-dihydroxycarbamazepine (CBZ-diol) and 10,11-dihydro-10,11-epoxycarbamazepine (CBZ-epoxide) have been found in water. Several monitoring studies carried out in Europe, America, and Asia have detected CBZ in the aquatic environment at the highest frequency compared to the other pharmaceutical micropollutants. It is most frequently detected in sewage treatment plants effluents, in river water, and in seawater [15]. It was found at the highest concentration of $1.075 \mu \mathrm{g} / \mathrm{L}$ in surface waters in Germany [16], but also at $2.3 \mu \mathrm{g} / \mathrm{L}$ in Canada in wastewater effluent [17]. The toxicity of CBZ at such low levels is not ascertained; the risk does not seem immediate, so the main concerns are the accumulation of CBZ in the aquatic ecosystems and the potential cocktail effects in synergy with other micropollutants [18].

Wastewater treatment plants (WWTPs) have been identified as the most relevant sources of pollution with this molecule. Indeed, the average removal rate of CBZ by the conventional activated sludge process is below $10 \%$, and that it is not significantly improved by the use of modern configurations such as membrane bioreactors, though these are frequently effective at removing other pharmaceuticals $[19,20]$. The same is reported for sequencing batch reactors in which CBZ appears to be resistant to microbial biodegradation [21]. However, other alternatives are more efficient: biological treatments with Trametes versicolor, for example, with laccase, eliminated about $60 \%$ of CBZ after $48 \mathrm{~h}$ of contact time [22]. The first drawback of the biological processes, in general, is the possible biodegradation of CBZ into more toxic compounds. The second is that removal may be driven by a 
biosorption or bioaccumulation mechanism, which only displaces the pollutant. Many studies have tested the toxicity of CBZ in various microorganisms. For instance, CBZ toxicity was tested on the green algae Ankistrodesmus braunii (A. braunii) and Selenastrum capricornutum [23]. They found that no toxic effect on $A$. braunii could be observed by working at very low concentrations of CBZ and that over $50 \%$ of CBZ had been removed in 60 days. Other recent studies focused on the investigation of the microalgae abilities in the elimination of this molecule. Table 2 summarizes the obtained results in terms of removal efficiency as well as the used algal species and cultivation conditions. None or a negligible removal has been reported in some cases, while in other studies, elimination yields between $30 \%$ and $50 \%$ were reported.

Table 2. Removal of carbamazepine (CBZ) from aqueous solutions by microalgae.

\begin{tabular}{ccccc}
\hline Algal Species & $\begin{array}{c}\text { Cultivation } \\
\text { Conditions } \\
\text { (Culture Media, } \\
\text { Temperature and } \\
\text { Cultivation Time) }\end{array}$ & $\begin{array}{c}\text { CBZ } \\
\text { Concentration }\end{array}$ & $\begin{array}{c}\text { Removal } \\
\text { Efficiency }\end{array}$ & Reference \\
\hline $\begin{array}{c}\text { Spirulina platensis } \\
\text { FACHB-431 }\end{array}$ & $\begin{array}{c}\text { Zarrouk medium, } 27 \pm \\
1{ }^{\circ} \mathrm{C}, \\
10 \text { days }\end{array}$ & $\begin{array}{c}1-5 \mathrm{mg} / \mathrm{L} \\
1-5 \mathrm{mg} / \mathrm{L}+0.5 \mathrm{~g} / \mathrm{L} \\
\text { glucose }\end{array}$ & $\begin{array}{c}30-16(\%) \\
50-20(\%)\end{array}$ & {$[24]$} \\
\hline $\begin{array}{c}\text { Chlorella sp. and } \\
\text { Scenedesmus sp. }\end{array}$ & $\begin{array}{c}\text { Synthetic wastewater, } \\
23 \pm 5^{\circ} \mathrm{C}, 10 \text { days }\end{array}$ & $5 \mu \mathrm{\mu g} / \mathrm{L}$ & $20 \%$ & {$[25]$} \\
\hline $\begin{array}{c}\text { Ceratozamia } \\
\text { mexicana }\end{array}$ & $\begin{array}{c}\text { Bold's basal medium } \\
27^{\circ} \mathrm{C}, \\
10 \text { days }\end{array}$ & $1-25 \mathrm{mg} / \mathrm{L}$ & $37-21 \%$ & {$[26]$} \\
\hline $\begin{array}{c}\text { Scenedesmus } \\
\text { obliquus }\end{array}$ & $\begin{array}{c}\text { Bold's basal medium } \\
27^{\circ} \mathrm{C}, \\
10 \text { days }\end{array}$ & $1-25 \mathrm{mg} / \mathrm{L}$ & $30-13 \%$ & [26] \\
\hline $\begin{array}{c}\text { Microalgae } \\
\text { consortia }\end{array}$ & $\begin{array}{c}\text { Domestic wastewater, } \\
2{ }^{\circ} \mathrm{C}, \mathrm{HRT}=4.5 \text { days }\end{array}$ & $<33 \mathrm{ng} / \mathrm{L}$ & no removal & {$[27]$} \\
\hline $\begin{array}{c}\text { Chlorella sorokiniana } \\
\text { Anaerobic black water } \\
35^{\circ} \mathrm{C}, 31 \text { days }\end{array}$ & $100-35 \mu \mathrm{g} / \mathrm{L}$ & $10 \%$ & {$[28]$} \\
\hline
\end{tabular}

Other work has highlighted that CBZ represents a challenge in terms of efficient elimination strategy [24].

In practice, physicochemical treatments of CBZ were often found to be more efficient than biological treatments. For example, membrane processes with reverse osmosis showed more than $85 \%$ elimination of CBZ and of other pharmaceutical compounds [29]. Moreover, ozonation removed up to $99 \%$ even when present in trace concentrations [30]. Additionally, Fenton and photo-Fenton processes showed complete elimination of CBZ by Fenton oxidation [31], and heterogeneous photocatalytic processes achieved more than $90 \%$ elimination [32]. Hybrid processes that consist of the combination of several conventional processes were also investigated and found efficient for $\mathrm{CBZ}$ elimination. For instance, in the treatment based on $\mathrm{UV} / \mathrm{H}_{2} \mathrm{O}_{2}$, the presence of $25 \mathrm{mg} / \mathrm{L}$ of $\mathrm{H}_{2} \mathrm{O}_{2}$ eliminated $90 \%$ of $\mathrm{CBZ}$ at $2.25 \mathrm{~J} / \mathrm{cm}^{2} \mathrm{UV}$ dose [33]. Ozonation, as Fenton and photocatalytic processes, belong to the class of advanced oxidation processes (AOPs). Despite their ability to eliminate rapidly highly biorefractory chemicals, such as CBZ, they present; however, there are two major drawbacks:

- Their cost is too high.

- Mineralization is not complete, and they may also produce secondary pollutants [34].

This is the reason why research still focuses on the development of innovative biological treatments, for example involving the bioaugmentation of activated sludge.

In this work, the objective was to investigate the potential of the green microalgae A. braunii for CBZ removal. Andreozzi et al. [23] have investigated the toxicity of this molecule on A. braunii and 
noted that about $50 \%$ of the initial CBZ had been removed after 60 days. At the moment, it is still unknown whether these algae are able to degrade or transform this refractory pharmaceutical molecule and even less about the degradation mechanism. The aim was to confirm this result at various CBZ initial concentrations using two culture media, the inorganic Bold's Basal (BB) medium and a proteose peptone (PP) medium, to enhance autotrophic and heterotrophic growth, respectively, both for different inoculum concentrations as a function of cultivation time. First, the influence of CBZ on the growth of the algae will be studied. Then, the elimination of CBZ was investigated quantitatively over time. Finally, the mechanism of CBZ removal was analyzed.

\section{Materials and Methods}

\subsection{Chemicals}

Carbamazepine (99.8\% pure) was purchased from Sigma-Aldrich (St. Louis, MO, USA). Acetonitrile of HPLC (High Performance Liquid Chromatography) grade was supplied by Sigma-Aldrich (St. Louis, MO, USA). All other chemicals used for analytical purposes or for culture media formulation were of analytical grade and were obtained from Sigma-Aldrich (St. Louis, $\mathrm{MO}$, USA). Ultrapure water was produced by an Elga Option-Q DV-25 system (eBay Inc, SAN Jose, CA, USA).

\subsection{Ankistrodesmus Braunii and Culture Media}

The algae tested for the elimination of CBZ was Ankistrodesmus braunii, strain CCAP 202/7a, from the Culture Collection of Algae and Protozoa (CCAP, Ambleside, UK). A. braunii was cultivated in two liquid culture media having different elemental compositions: namely, the Bold's basal medium (BB) and the proteose peptone medium (PP) to compare the relative growth of the algae and its ability to remove $\mathrm{CBZ}$ in these media. The components of these liquid culture media and the used protocols are described below. For the $\mathrm{BB}$ media, different salt stock solutions at a given concentration were prepared as follows: $\mathrm{NaNO}_{3}(5.0 \mathrm{~g} / 200 \mathrm{~mL}), \mathrm{MgSO}_{4}(1.5 \mathrm{~g} / 200 \mathrm{~mL}), \mathrm{NaCl}(0.5 \mathrm{~g} / 200 \mathrm{~mL}), \mathrm{K}_{2} \mathrm{HPO}_{4}$ $(1.5 \mathrm{~g} / 200 \mathrm{~mL}), \mathrm{KH}_{2} \mathrm{PO}_{4}(3.5 \mathrm{~g} / 200 \mathrm{~mL})$, and $\mathrm{CaCl}_{2} \cdot 2 \mathrm{H}_{2} \mathrm{O}(0.5 \mathrm{~g} / 200 \mathrm{~mL})$. Stock solutions were stored unsterilized at $4{ }^{\circ} \mathrm{C}$. Culture media was prepared by combining $10 \mathrm{~mL}$ of each of the six stock solutions with $1 \mathrm{~mL}$ of each of the following solutions: alkaline EDTA $(5.0 \mathrm{~g} / 100 \mathrm{~mL}$ of EDTA-KOH), acidified iron $\left(4.98 \mathrm{~g} / \mathrm{L}\right.$ of $\mathrm{FeSO}_{4}$ and $1 \mathrm{~mL}$ of $\left.\mathrm{H}_{2} \mathrm{SO}_{4}\right)$, boron $\left(1.14 \mathrm{~g} / \mathrm{L}\right.$ of $\left.\mathrm{H}_{3} \mathrm{BO}_{3}\right)$ and trace metals solution. The volume was finally filled up to $1 \mathrm{~L}$ with ultrapure water. The metals solution used was composed of: $8.82 \mathrm{~g}$ of $\mathrm{ZnSO}_{4}, 1.44 \mathrm{~g} \mathrm{MnCl}_{2} .4 \mathrm{H}_{2} \mathrm{O}, 0.71 \mathrm{~g}$ of $\mathrm{MoO}_{3}, 1.57 \mathrm{~g}$ of $\mathrm{CuSO}_{4}$, and $0.49 \mathrm{~g}$ of $\mathrm{Co}\left(\mathrm{NO}_{3}\right)_{2} \cdot 6 \mathrm{H}_{2} \mathrm{O}$ dissolved in $1 \mathrm{~L}$ ultra-pure water. The proteose peptone medium contained per liter: $20 \mathrm{~mL}$ of each of the following stock solutions $\left(\mathrm{MgSO}_{4}(1.0 \mathrm{~g} / \mathrm{L}) ; \mathrm{K}_{2} \mathrm{HPO}_{4}(1.0 \mathrm{~g} / \mathrm{L}) ; \mathrm{KNO}_{3}(10.0 \mathrm{~g} / \mathrm{L})\right)$ and $1 \mathrm{~g}$ of proteose peptone powder. The $\mathrm{pH}$ of both culture media was adjusted to 7 with $\mathrm{NaOH}(1 \mathrm{mM})$ and then sterilized in an autoclave for $15 \mathrm{~min}$ at $120^{\circ} \mathrm{C}$.

\subsection{Growth Experiments}

The precultures were conducted in Erlenmeyer flasks containing $100 \mathrm{~mL}$ of the considered medium aseptically inoculated with $10 \mathrm{~mL}$ of CCAP algae suspension. These cultures were kept to grow reasonably dense under controlled light and temperature conditions $(23 \pm 1){ }^{\circ} \mathrm{C}$, irradiance $100 \mu \mathrm{Es}^{-1} \cdot \mathrm{m}^{-2}$, the day and night pattern was a $16 \mathrm{~h}$ day and an $8 \mathrm{~h}$ night, using Philips Master (TL-D 18W/827 lamps, Pila, Poland) in a stove (INFROS, Basel, Switzerland). The obtained precultures were then used to inoculate the cultures for the degradation experiments. These tests were carried out in batch mode, in conical flasks containing $1 \mathrm{~L}$ of culture medium at two different pollutant concentrations 2.5 and $10 \mathrm{mg} / \mathrm{L}$, which corresponds to the highest CBZ concentrations studied in the case of hospital wastewater [35]. CBZ was directly dissolved in the culture media (BB or PP) to give the desired initial concentration. Erlenmeyer flasks were autoclaved at $121{ }^{\circ} \mathrm{C}$ for 15 min prior to inoculation to avoid contamination and provide rapid dissolution of CBZ. No degradation of CBZ 
was observed during autoclaving. For these cultures, two different initial biomass concentrations $\left(10^{4}\right.$ and $10^{5}$ cells $/ \mathrm{mL}$ ) were used in order to investigate the influence of this parameter on algae growth and CBZ biodegradation. Flasks were then incubated as a reference at $30^{\circ} \mathrm{C}$ for up to 60 days under agitation at $135 \mathrm{rpm}$, which can be compared with the conditions of mesophilic anaerobic digestion and also to the data of Andreozzi et al. [23] on A. braunii. The agitation rate was chosen from the range of $100-150 \mathrm{rpm}$, which is usually used to inoculate algae [36,37]. Appropriate controls without the target compound were conducted for each of the tested cultures conditions to investigate the algal growth, but also for analytical purposes. Indeed, the controls allow distinguishing metabolites resulting from the breakdown of CBZ from those arising from the base metabolism of algae. Thus, twelve different experimental conditions were investigated in duplicate to evaluate the growth of $A$. braunii as well as CBZ degradation. Samples $(2 \mathrm{~mL})$ were taken at different time intervals and evaluated for cell concentration and CBZ concentration, as described below. Culture transfer and sampling were done aseptically to minimize contamination.

\subsection{Microscopy}

The growth of algae during all the experiments was followed by cell counting using a Malassez hemocytometer (Tiefe Depth, $0.200 \mathrm{~mm}$ ) and a microscope (Olympus BX41TF, Tokyo, Japan) at a magnification $\times 100$ (oil immersion lens) in the absence and in the presence of CBZ at regular time intervals ( 2 days) over a period of 60 days, on each of the twelve culture conditions described above. Microscopy was also employed for the morphological observation of algal culture during different tests and to ensure the complete bursting under high-pressure conditions of the algal cells.

\subsection{Analytical Procedure}

\subsubsection{HPLC-DAD Analysis}

Samples taken from each of the cultures were filtered using adequate polyester filters (Chromafil Xtra PET, $0.45 \mu \mathrm{m}, 25 \mathrm{~mm}$ diameter) and transferred to HPLC vials for subsequent HPLC determination. The quantification of CBZ in the different samples was carried out on HPLC (Waters 2410, Saint-Quentin-en-Yvelines, France) equipped with a diode array detector (DAD) using a reverse-phase C18 column (Waters, Symmetry: $5 \mu \mathrm{m}, 4.6 \mathrm{~mm} \times 250 \mathrm{~mm}$ ). The mobile phase was acetonitrile in ultra-pure water $(30: 70 \mathrm{v} / \mathrm{v})$, and detection was carried out at the wavelength $\lambda=230 \mathrm{~nm}$. The flow rate was $0.5 \mathrm{~mL} / \mathrm{min}$. The analysis was conducted in isocratic mode and the retention time of CBZ was about $20 \mathrm{~min}$.

\subsubsection{Identification of CBZ Metabolites}

Organic reaction intermediates obtained under optimum process conditions were identified using an ultraperformance liquid chromatography-tandem mass spectrometry (UHPLC/MS/MS). The analyses were performed with an Acquity ${ }^{\mathrm{TM}}$ UHPLC H-Class system (Waters, Saint-Quentin-en-Yvelines, France) coupled with a Waters Acquity ${ }^{\mathrm{TM}}$ triple quadrupole mass spectrometer (MS/MS) equipped with an electrospray ionization source. The separation was achieved with a reversed-phase column BEH C18 $(50 \mathrm{~mm} \times 2.1 \mathrm{~mm}, 1.7 \mu \mathrm{m})$ placed in an oven at $45^{\circ} \mathrm{C}$. Elution was carried out with a mixture of acetonitrile/ultrapure water (30/70 ratio) containing $0.1 \%(v / v)$ of formic acid and in isocratic mode with a flow rate of $0.5 \mathrm{~mL} \cdot \mathrm{min}^{-1}$. For the analysis, a sample volume of $5 \mu \mathrm{L}$ was used. The MS analyses were carried out in positive mode electrospray ionization.

\subsubsection{Analysis of CBZ Bioaccumulation in A. braunii}

Samples taken from the reference solutions of CBZ in BB and PP in the absence of algae were analyzed first using HPLC to identify the effect, if any, of the high temperature used to sterilize and dissolve the CBZ on the CBZ elimination. These preliminary results confirmed that in the absence of algae and at high temperature, no possible chemical degradation of CBZ could occur. Bioaccumulation 
was supposed to be the main removal mechanism of CBZ [34]. To check the fate of and mechanisms for CBZ elimination by A. braunii, cells were burst at $239 \mathrm{MPa}$ using high-pressure cell disruption equipment (Constant systems, Daventry, UK), and the CBZ concentration was then measured by HPLC using the procedure described above. Cells lysis was confirmed by microscopic examination employing an electronic microscope (Olympus CX41, Tokyo, Japan) coupled to a camera (QImaging, Vancouver, Canada). This method gave access to bioaccumulated CBZ.

\section{Results and Discussion}

\subsection{Effect of CBZ on the A. braunii Growth}

The growth of the A. braunii was followed in both culture media in the absence and in the presence of CBZ to detect whether there would be any effect after the addition of CBZ at both initial inoculum concentrations of $10^{4}$ and $10^{5}$ cells $/ \mathrm{mL}$. The growth curves (data from the measurements using a Malassez cell) are reported in Figure 1 at the two initial inoculum concentrations. First, all the curves in the figure showed a short latent phase for both media without CBZ of about five days. However, the latent phase was longer when the pollutant was added to both media, at about eight days for both tested inoculum concentrations. This is probably due to the time necessary for the algae to adapt to the presence of the pollutant in the culture media.

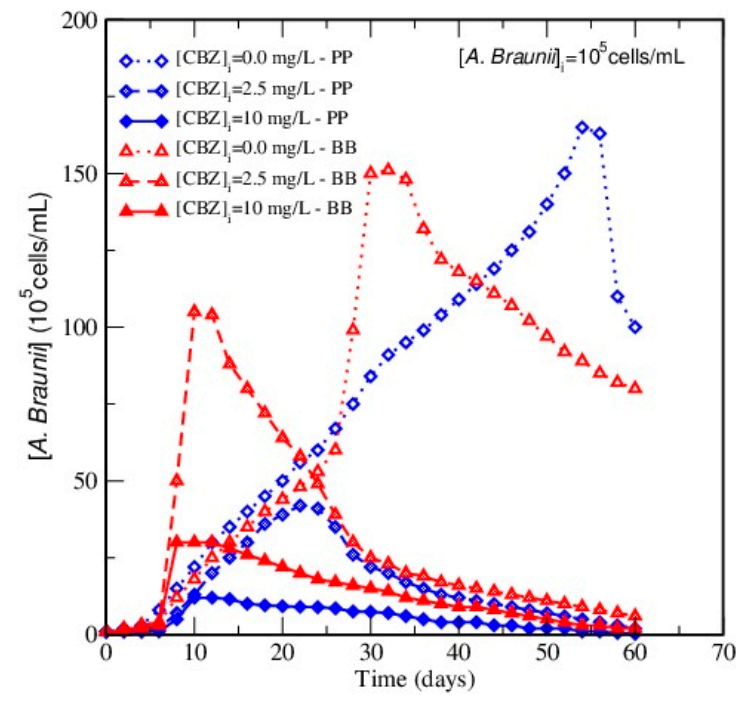

(a)

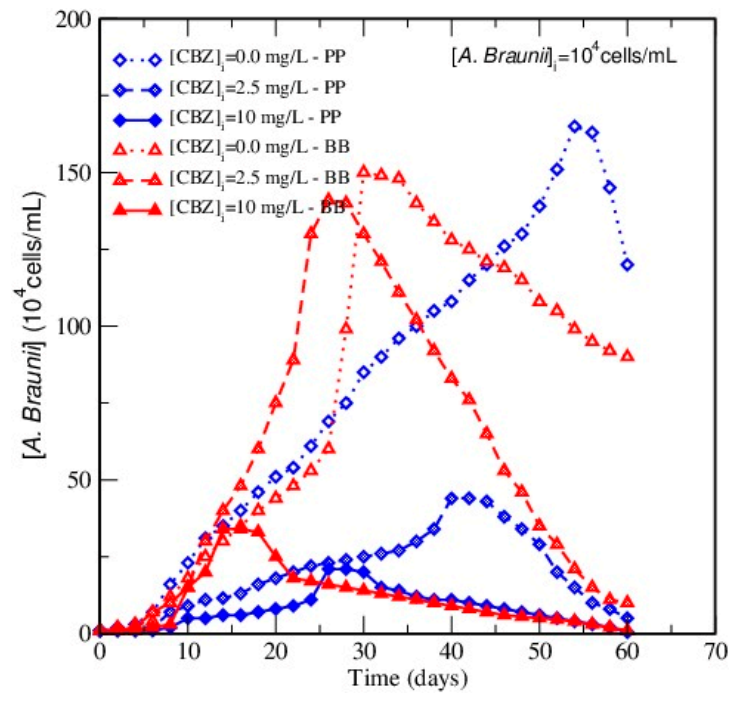

(b)

Figure 1. Growth curves of Ankistrodesmus braunii cultured in Bold's Basal (BB) and proteose peptone (PP) media at different initial CBZ concentrations $(0.0,2.5$, and $10 \mathrm{mg} / \mathrm{L}$, respectively) for an initial inoculum concentration (a) $10^{5}$ cells $/ \mathrm{mL}$, (b) $10^{4}$ cells $/ \mathrm{mL}$, during 60 days of incubation.

When comparing growth rates, it was found that the algae in the absence of CBZ had, first, approximately the same growth rates in both media. Discrepancies emerged after 25 days, as growth rates suddenly rose steeply in $\mathrm{BB}$, whereas it followed the same trend with a constant slope in PP. This might be due to the difference in nutritive content, particularly the nitrogen source: proteose peptone of bovine source in PP and EDTA in BB, respectively. As a result, growth was faster in BB than in PP in the absence of $\mathrm{CBZ}$, but the exponential growth phase was shorter, and the death phase started earlier in BB. The consequence is that the maximum amount of algae biomass was higher in PP but was reached far later than in BB. However, it must be pointed out that the amount of algae present was still considerable after 60 days of incubation; due to the delayed maximum, the algae concentration was higher in PP, but the death rate was also higher, while it followed a smooth decreasing shape in BB. The comparison between Figure $1 \mathrm{a}, \mathrm{b}$ also show that the algae concentrations exhibited exactly the same shape when the inoculum concentration was changed and that, at any time $(t)$, the algae 
concentration was roughly proportional to the inoculum concentration in the absence of CBZ, which means that maximum algae concentrations were observed at the same time, independently from the inoculum concentration without CBZ.

Conversely, this pattern changed greatly when CBZ was present in both media in Figure 1. The addition of CBZ shortened the growth phase in both cases. Consequently, the onset of the death phase started earlier, a lower maximum biomass concentration was achieved than without CBZ, and an almost complete death was observed at the end of the 60 days of cultivation. However, differences emerging from the presence of $C B Z$ were media-dependent. For example, the maximum algae concentration was observed in $\mathrm{BB}$, while it was reported in PP without CBZ. The comparison of the results obtained for the cultures with and without $C B Z$ highlighted that the maximum algae concentrations fell due to CBZ in PP, while they were only slightly decreased in BB. A striking result was also that the rapid increase of the algae concentration was forwarded in BB in Figure 1, but with growth rates nearly as high as without CBZ. This differed strongly in PP: although the maximum algae concentration was also forwarded, the values and the growth rate were always smaller than without CBZ. The comparison between Figure $1 \mathrm{a}, \mathrm{b}$ also highlighted that if the maximum algae concentration was nearly divided by a factor of ten when the inoculum concentration was reduced from $10^{5}$ to $10^{4}$ cells/mL (as without CBZ), the time at which this maximum was achieved depended strongly on the inoculum concentration when CBZ was present in both media, which was not observed without CBZ. This showed clearly that the ratio between inoculum and CBZ concentrations played a key role in the A. braunii growth.

The differences between $\mathrm{BB}$ and PP could be related to a possible interaction of CBZ with the proteose peptone in PP, as CBZ is known to interact with proteins [38]. This would lead to a decrease in the amount of the proteins available for the algae to grow, and consequently to a weaker growth rate. However, no interaction between the proteose peptone medium and CBZ was found using HPLC, although this could vanish in the acetonitrile/water eluent. Another explanation is that CBZ is toxic for A. braunii, but that CBZ assimilation is less rapid in the presence of EDTA (nutritive source of $\mathrm{C}$ and $\mathrm{N}$ in $\mathrm{BB}$ ), which also accelerated algae growth under these conditions. Conversely, the rapid algae death that followed could be attributed to a toxic effect of CBZ under EDTA limitation. This contradicts the results of Andreozzi et al. [23], who reported no toxicity of CBZ on A. braunii, but used a far lower initial concentration of CBZ, about $2.1 \times 10^{-6} \mathrm{~g} / \mathrm{L}$. Finally, for the efficient and rapid growth of $A$. braunii microalgae, experimental data shows that PP should be preferred, but in the presence of $\mathrm{CBZ}, \mathrm{BB}$ should be used because of the evidenced strong interaction between $\mathrm{CBZ}$ and algae growth.

Consequently, the influence of the initial CBZ concentration was investigated for both media and initial inoculum concentrations. Two initial CBZ contents $(2.5 \mathrm{mg} / \mathrm{L}$ and, $10 \mathrm{mg} / \mathrm{L}$, respectively) were investigated in this work. Experimental results showed that, for all the experiments, a higher concentration of the pollutant further shortened the exponential growth phase and lowered the obtained maximum algae concentration. Indeed, a high initial CBZ content forwarded the onset of the death phase and led to an earlier A. braunii death when compared to working at $2.5 \mathrm{mg} / \mathrm{L}$ of CBZ. Roughly, when the initial CBZ concentration was multiplied by a factor of four, the maximum concentration of algae was divided by the same factor. In addition, the growth profiles of the microalgae presented the same shape for both of the tested inoculum concentrations, but kinetics showed an interaction between CBZ and algae contents. Thus, when the initial inoculum concentration was multiplied by a factor of ten, the culture time necessary to reach the maximum algae concentration was divided approximately by a factor of two at constant initial CBZ concentration, whatever the considered initial pollutant concentration.

In conclusion, the obtained data clearly showed that the presence of the target compound did not repress $A$. braunii growth, despite its continuous exposure. For all tested conditions, the algae successfully grew in the presence of CBZ. This result is in agreement with previous studies that reported that the toxicity of organic compounds on cells could be attenuated by the uptake of non-toxic nutriments, such as the alternative carbon sources [39-41]. However, the initial CBZ concentration 
impaired the duration of the exponential phase of the growth phase, and the maximum cell number was reduced for all of the investigated conditions when the initial CBZ content was increased. Thus, the presence of the pollutant negatively affected the metabolic reactions associated with the algae's main metabolism (growth media BB or PP without CBZ). These trends corroborate the probable toxicity of $\mathrm{CBZ}$ on A. braunii, which increased with the initial xenobiotic concentration. Similar results were reported by [42] for the growth of Staphylococcus xylosus in the presence of 2,4 dichlorophenol. In addition, the above results also indicate that an additional carbon source is needed to support cell growth in the presence of toxic compounds such as CBZ.

\subsection{Effect of the Culture Conditions on the Pollutant Elimination}

\subsubsection{Effect of Culture Medium}

The effect of the composition of culture media used for the A. braunii growth on the removal of $\mathrm{CBZ}$ was investigated. Figure 2 plots the time profiles for the residual CBZ concentration for both of the investigated culture media and an initial inoculum and pollutant concentration of $10^{4}$ cells $/ \mathrm{mL}$ and $10 \mathrm{mg} / \mathrm{L}$, respectively. As shown in this figure, the evolution of CBZ concentration over time exhibited the same profile in both media. Three phases are really discriminated for both investigated media: first, it was constant or decreased slightly, and then, a steep decrease was reported, followed by a slow decrease of CBZ content. The key difference between BB and PP media was the period at which the steep decrease was reported: it occurred 12 days before in BB than in PP. BB was shown to be more favorable than PP for the CBZ elimination after 60 days of incubation, as a higher removal yield was achieved. For example, with an inoculum concentration of $10^{4}$ cells $/ \mathrm{mL}$ and an initial CBZ content of $10 \mathrm{mg} / \mathrm{L}$, this yield was 70\% \pm 4 in BB medium, but only $66 \% \pm 3$ in PP. However, the BB medium also led to faster removal. This is in accordance with the results presented previously.

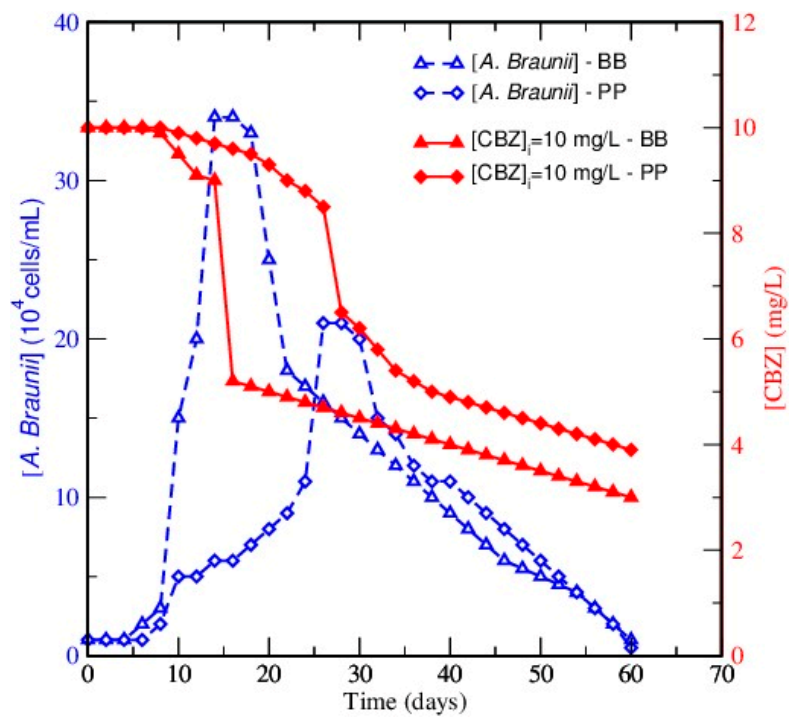

Figure 2. Effect of the culture media on CBZ removal for an initial pollutant concentration of $10 \mathrm{mg} / \mathrm{L}$ and an initial inoculum concentration of $10^{4}$ cells $/ \mathrm{mL}$.

A. braunii cell concentration and CBZ elimination increased simultaneously, suggesting that CBZ could be used as a nutritive source by the microalgae, but other explanations can be found. For example, these trends could also be related to a bioaccumulative, biosorptive, or metabolic role of A. braunii, as the kinetics of these mechanisms are also proportional to the amount of algae. The results presented here are not unexpected, as algae are known to be able to degrade recalcitrant organic compounds. Indeed, Todd et al. [43] demonstrated the biotransformation of naphthalene and diaryl ethers, complex aromatic pollutants, by Chlorella, Ankistrodesmus, and Scenedesmus strains. Other studies reported 
that numerous algal strains induce biotransformation of exogenous steroids or low-molecular-weight phenols [44-46]. However, to the best of our knowledge, no previous study has demonstrated the removal of CBZ with algae pure cultures.

For a better understanding of experimental results, the growth curves and the residual CBZ concentration were plotted together in Figure 2 for each tested culture medium. The obtained data highlights an interaction between these two parameters: the delayed exponential growth phase in PP led to a delayed death phase and to a delayed onset of CBZ elimination. The role of A. braunii in CBZ elimination is, therefore, assured by comparing growth kinetics and the consequent CBZ amount in both culture media. Figure 2 showed a synchronized behavior between the A. braunii cell growth and the residual amount of CBZ. For example, when working at an initial inoculum concentration of $10^{4}$ cells $/ \mathrm{mL}$ and an initial CBZ concentration of $10 \mathrm{mg} / \mathrm{L}$, the amount of CBZ at the very beginning of the culture was almost stable during the first five to eight days corresponding to the latent phase of the algae, but this was followed by a rapid decrease of CBZ concentration that took place at the time where the highest cell concentration is attained in both BB and PP. Thus, during the first phase, cells seem to prepare themselves to better assimilate the pollutant, and no appreciable changes in the biomass and CBZ concentration were observed. The improved performance of $A$. braunii in the removal of the xenobiotic compound becomes effective during the second phase when a rapid increase in the growth rate and pollutant consumption was observed. Finally, the removal of the target pollutant continues during the negative cell-growth period. A similar trend was observed by Saéz and Rittmann [39] for the elimination of 4-chlorophenol by Pseudomonas putida.

In conclusion, it can be noticed that the presented data assess the role of $A$. braunii on CBZ removal in both media and that CBZ removal was enhanced in BB in comparison to PP, noting that the growth of the algae was also favored in BB in the presence of CBZ. Moreover, it should be pointed out that the addition of conventional carbon sources in the culture medium can substantially modify the cell density, especially the extracellular enzymes under the considered conditions (as expected, when autotrophic growth is replaced by mixotrophic or heterotrophic conditions [47]) and as a consequence, the removal of the target compound. Other studies also reported for bacteria the positive role of additional carbon sources via a co-metabolism in the removal of toxic organic compounds [48-51]. Similarly, the literature reports that a primary electron-donor substrate is required to grow and sustain the biomass capable of degrading any co-metabolite, which is an obligate secondary substrate [39], which may also explain our experimental results.

\subsubsection{Effect of Inoculum Concentration on the Removal of CBZ}

To further clarify the effect of inoculum concentration, a new set of experiments was carried out in order to follow the effect of the initial inoculum concentrations $\left(10^{4}\right.$ and $10^{5}$ cells $\left./ \mathrm{mL}\right)$ on the elimination of CBZ. The tests were carried out at both initial concentrations of CBZ (2.5 and $10 \mathrm{mg} / \mathrm{L})$ and in both media (BB and PP). By comparing the HPLC data, it was shown that the removal yield of CBZ was enhanced and that the onset of CBZ elimination was forwarded by the highest initial A. braunii inoculum concentration $\left(10^{5} \mathrm{cells} / \mathrm{mL}\right)$ in both culture media and for both CBZ initial concentrations (Figure 3a,b).

For example, it was shown in these figures that in BB medium for the same initial CBZ concentration of $2.5 \mathrm{mg} / \mathrm{L}$, an increase in the removal of CBZ from $80 \%$ to the highest elimination percentage attained of $87 \%$ in this work was observed after 60 days of incubation when the concentration of $A$. braunii increased from $10^{4}$ to $10^{5}$ cells/mL. However, it must be pointed out that the increase in removal yield due to higher inoculum content from $10^{4}$ to $10^{5}$ cells $/ \mathrm{mL}$ never exceeded $8 \%$, whatever the removal yield, and that it never approached complete removal. This may be explained as follows: While the additional amount of the eliminating agent, the algae, led to an improved elimination of CBZ, the medium was exhausted more rapidly due to a stronger competition on nutritive sources. As a result, the algae started more rapidly to consume CBZ as the only possible nutritional source, and a higher 
quantity of algae was removed from the water, but toxic effects of CBZ also grew simultaneously and prevented a complete elimination of this molecule.

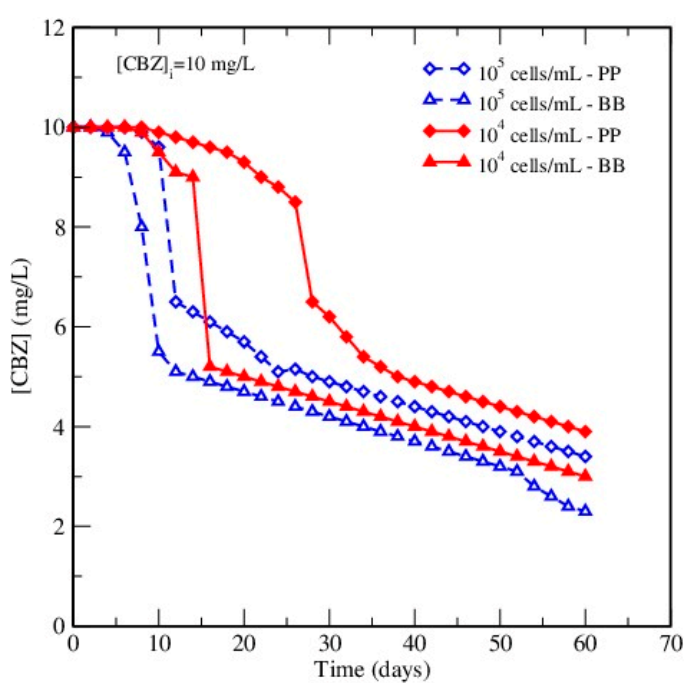

(a)

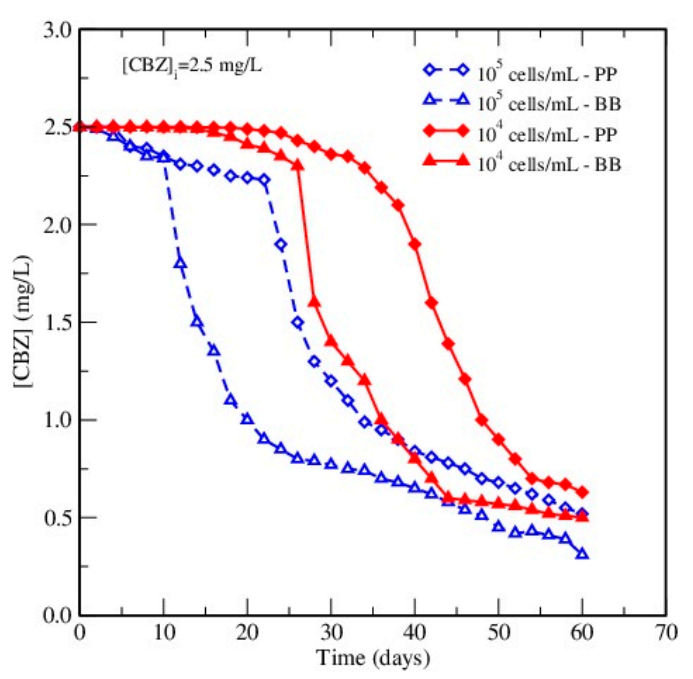

(b)

Figure 3. Effect of inoculum concentration on the removal of CBZ in both media at: (a) $10 \mathrm{mg} / \mathrm{L}$, and (b) $2.5 \mathrm{mg} / \mathrm{L}$ of CBZ.

In conclusion, CBZ removal could be enhanced by increasing the initial inoculum concentration and, more generally, by increasing the concentration of algae in both media, even though a complete elimination could not be achieved. It is important to notice that the concentrations tested in this work were higher than those presented in the influents of the wastewater treatment plants (in the $\mu \mathrm{g} / \mathrm{L}$ range). However, it is also important to take into account that pharmaceuticals are not always detected at trace levels. Thus, in their work, Larsson et al. [52] reported high concentrations of pharmaceutical compounds for effluents from the healthcare industry: some of the mentioned molecules exhibited concentrations of the same order of magnitude as in this study (concentrations levels of 28, 2.4, and $1.3 \mathrm{mg} / \mathrm{L}$ were detected for ciprofloxacin, losartan, and cetirizine, respectively). The main objective of our work at this point was to evaluate if the considered algae are able to degrade this refractory pharmaceutical compound. The next step will be focused on the design of degradation tests in culture conditions closer to the real ones (micropollutant concentration, $\mathrm{pH}$, temperature, and real wastewater).

\subsubsection{Effect of CBZ Initial Concentration on Its Elimination}

The effect of the initial concentration of CBZ was analyzed using experimental data at two initial CBZ concentrations of 2.5 and $10 \mathrm{mg} / \mathrm{L}$, in both media, starting with both initial inoculum concentrations. Experimental results in Figure 4 showed that the increase of the initial CBZ concentration led to a decrease in the percentage of its elimination in both media. For instance, for the same A. braunii inoculum concentration $10^{5}$ cells $/ \mathrm{mL}$, increasing the initial CBZ concentration from 2.5 to $10 \mathrm{mg} / \mathrm{L}$ in PP medium induced a decrease in the percentage of elimination from $79.2 \%$ to $66.0 \%$ after 60 days.

This increase also forwarded the onset of the elimination of CBZ, and it is worth noting that this corresponded to the relative growth of $A$. braunii at the time. This resulted in a more rapid elimination but with a lower final yield when starting with $10 \mathrm{mg} / \mathrm{L}$ of CBZ than when starting with $2.5 \mathrm{mg} / \mathrm{L}$. 


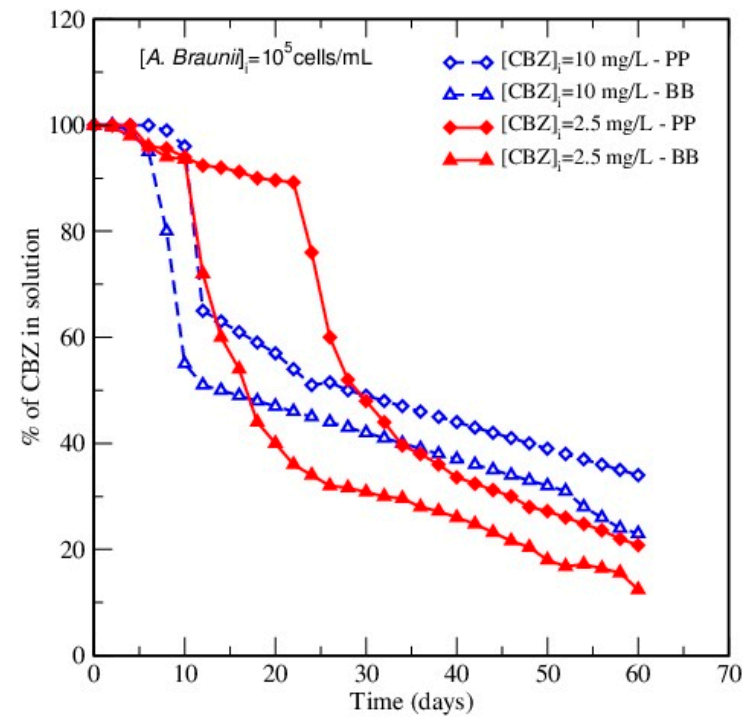

(a)

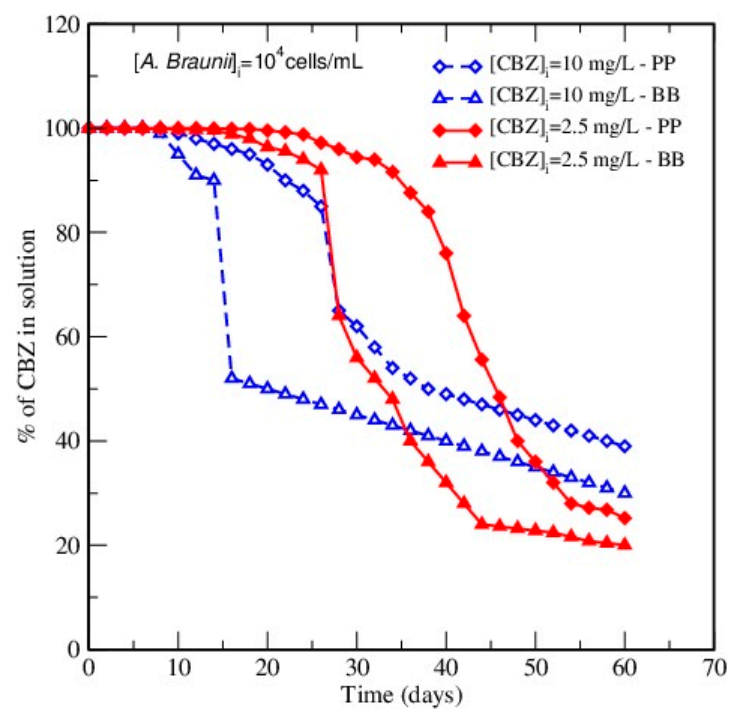

(b)

Figure 4. Effect of CBZ initial concentration on the elimination of CBZ at initial A. braunii content: (a) $10^{5}$ cells $/ \mathrm{mL}$, and (b) $10^{4}$ cells $/ \mathrm{mL}$.

In fact, this is due, on the one side, to the more rapid consumption of the higher concentration of CBZ (10 mg/L), that turns out to be more toxic on A. braunii, leading to forwarded death, and on the other side, to the smaller amount of CBZ needed to be harvested by the same inoculum concentration when the initial CBZ content was $2.5 \mathrm{mg} / \mathrm{L}$, leading to a higher elimination yield and reduced toxicity. Indeed, it must be pointed out that even though the yield decreased, the amount of CBZ removed strongly increased when its initial content was increased by a factor of four. This highlights the dual role of $\mathrm{CBZ}$ as a substrate and a toxic compound for microalgae.

In conclusion, the elimination yield of CBZ is enhanced when the initial CBZ concentration decreases, as this causes a less toxic effect on the algae and hence, and enhanced capability for approaching a "complete" CBZ elimination. This is an advantage, as CBZ is usually present as a micropollutant in water, but the drawback is that a lower CBZ content induces slower elimination kinetics. Moreover, the obtained data indicate that $A$. braunii is able to utilize the target compound either as carbon or nitrogen source, whatever these are made available by simpler substrates in the culture media.

\subsubsection{Summary of the Removal Yield of CBZ after 60 Days}

The removal yield of CBZ as a function of culture media, initial inoculum concentrations, and initial concentration of CBZ after 60 days has been summarized in Table 3. This table shows that the values ranged between $60 \%$ and $90 \%$, which is quite high for a biological treatment, accounting for the biorefractory character of CBZ. This assesses the ability of $A$. braunii to remove CBZ. The results achieved in this work were quite similar to those reported for the degradation of carbamazepine or clofibric acid by white-rot fungi, including Trametes versicolor [53]. It is also important to note that the removal efficiencies obtained with $A$. braunii were much higher than the ones reported previously based on the activated sludge systems [54,55].

As discussed before, Table 3 emphasizes that the lowest yields in both media corresponded to a high initial concentration of $10 \mathrm{mg} / \mathrm{L}$ of CBZ. It also shows that for any value of the initial concentration of $A$. braunii in both media, the removal yield decreased by about $10 \%$ for a factor of four increase in the initial concentration of CBZ. In addition to this, for any value of the initial concentrations of $\mathrm{CBZ}$, a factor of ten increase in the initial inoculum concentration leads to around a $7 \%$ increase in $\mathrm{CBZ}$ elimination. In other words, this shows that a factor of four increase of the initial concentration of CBZ had more influence than a factor of ten inoculum concentration on the elimination of CBZ. This 
demonstrates again the toxic effect of $\mathrm{CBZ}$ on $\mathrm{A}$. braunii in the range of concentrations studied, but also that this toxicity did not significantly impair the ability of the algae to remove CBZ.

Table 3. Removal yield of CBZ determined by HPLC for an initial CBZ content between 2.5 and $10 \mathrm{mg} / \mathrm{L}$, and an inoculum concentration between $10^{4}$ and $10^{5}$ cells $/ \mathrm{mL}$ after 60 days.

\begin{tabular}{cccc}
\hline $\begin{array}{c}\text { Initial Concentration of } \\
\text { CBZ }\end{array}$ & $\begin{array}{c}\text { Initial Concentration of } \\
\text { A. Braunii }\left(C_{\mathbf{i}}\right)\end{array}$ & $\begin{array}{c}\text { CBZ \% of Elimination } \\
\text { in PP Medium }\end{array}$ & $\begin{array}{c}\text { CBZ \% of Elimination } \\
\text { in BB Medium }\end{array}$ \\
\hline $2.5 \mathrm{mg} / \mathrm{L}$ & $10^{4} \mathrm{cells} / \mathrm{mL}$ & $74.8 \%$ & $80.0 \%$ \\
$2.5 \mathrm{mg} / \mathrm{L}$ & $10^{5} \mathrm{cells} / \mathrm{mL}$ & $79.2 \%$ & $87.6 \%$ \\
$10 \mathrm{mg} / \mathrm{L}$ & $10^{4} \mathrm{cells} / \mathrm{mL}$ & $61.0 \%$ & $70.0 \%$ \\
$10 \mathrm{mg} / \mathrm{L}$ & $10^{5} \mathrm{cells} / \mathrm{mL}$ & $66.0 \%$ & $77.0 \%$ \\
\hline
\end{tabular}

\subsubsection{Fate of $\mathrm{CBZ}$}

Besides studying the removal of the considered pharmaceutical compound, it is very important to investigate and determine the mechanism involved in the elimination of this molecule. Generally, different mechanisms such as biosorption, accumulation, and biotransformation are involved in the removal of organic pollutants [56,57]. However, they cannot be clearly distinguished since, for example, live cells can also degrade adsorbed pollutants by intracellular mechanisms [58]. In an effort to understand the mechanisms involved in the removal of CBZ by A. braunii, it is important to assess the transformation products. The first insights emerged in the HPLC chromatograms (obtained by successive analysis), which showed the presence of a new peak corresponding to an extracellular compound produced by the algae, the concentration of which increased in parallel to the decrease of CBZ. Being identified at the same wavelength, this exhibited a shorter retention time ( $3 \mathrm{~min}$, while the retention time of $\mathrm{CBZ}$ is $18 \mathrm{~min}$ ). As a consequence, this seemed to indicate the possible biotransformation of CBZ into metabolites and can be considered as an indicator of the biodegradation process.

To confirm this result and better analyze the fate and the mechanisms of elimination of CBZ by A. braunii, cells were burst under high pressure and then imaged to ensure the complete bursting of the cells so that the CBZ accumulated in the cells, if any, was released in the medium and easy to quantify by HPLC analysis. Figure 5 shows the magnified images of the cells with the elongated shaped $A$. braunii before pressure treatment and the randomly shaped destroyed cells after the cell burst. This also makes clear, as shown in Figure 5a, the asexual mode and binary fission of A. braunii reproduction in the presence of the target compound.

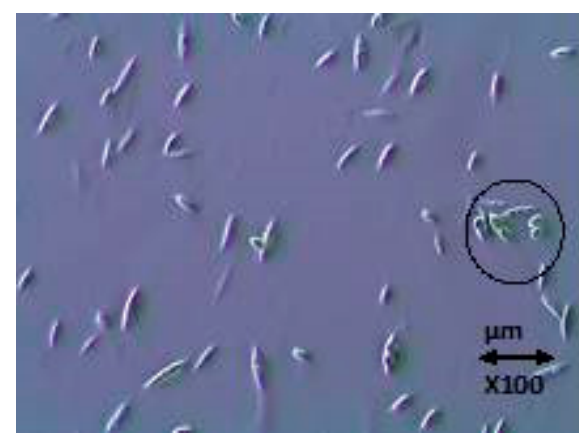

(a)

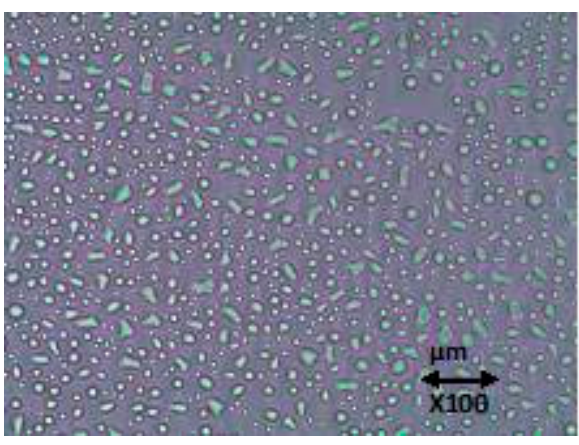

(b)

Figure 5. Magnified images of A. braunii, (a) non-burst, where the asexual reproduction of binary fission is shown in the circle, and (b) burst cells.

HLPC analysis of the liquid phase after A. braunii bursting showed that a high quantity of eliminated CBZ was recovered into the medium. Figure 6 gives a comparison of the CBZ concentrations determined in burst and non-burst cells cultured in BB and PP media. It can clearly be concluded 
from this figure that the bioaccumulation of CBZ in the cells played a key role in the removal of this molecule by A. braunii. However, it could also be observed that the total amount of CBZ found in the solution even after the algal bursting only corresponded to $80 \%$ of the initial CBZ concentration, which was $2.5 \mathrm{mg} / \mathrm{L}$. Surprisingly, the lowest amount of CBZ recovered in the medium corresponded to the case of the highest $\mathrm{CBZ}$ elimination, i.e., in the $\mathrm{BB}$ medium starting with $10^{5} \mathrm{cells} / \mathrm{mL}$ of $A$. braunii and $2.5 \mathrm{mg} / \mathrm{L}$ of CBZ.

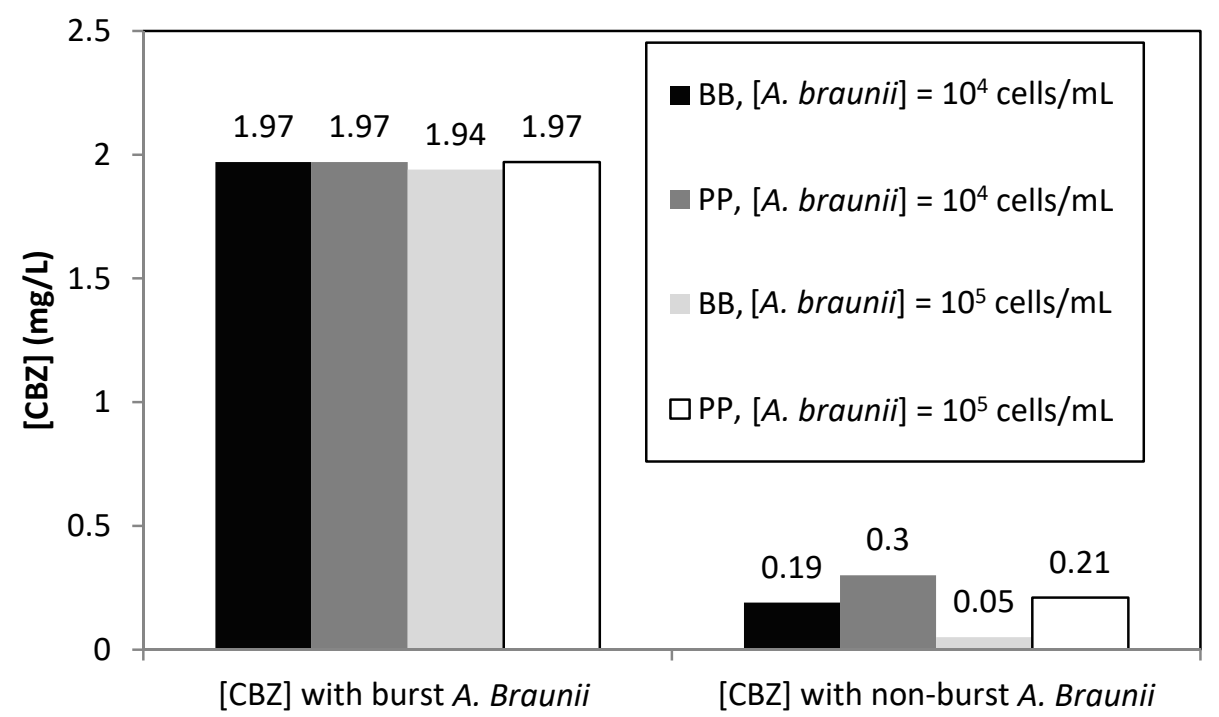

Figure 6. $\mathrm{CBZ}$ concentration in $\mathrm{BB}$ and PP media with burst and non-burst cells for an initial CBZ concentration of $2.5 \mathrm{mg} / \mathrm{L}$ and an inoculum concentration of A. braunii between $10^{4}$ and $10^{5}$ cells $/ \mathrm{mL}$.

Moreover, the HPLC data analysis also highlighted that the surface area of both the CBZ and the other peak increased simultaneously in both media after bursting $A$. braunii cells and that the area of the second peak was maximized in the BB medium starting with $10^{5}$ cells $/ \mathrm{mL}$ of $A$. braunii and $2.5 \mathrm{mg} / \mathrm{L}$ of CBZ (data not shown). These results confirm that these algae may take up this substrate into the cell, and another mechanism, namely biodegradation, occurs intracellularly in parallel to the bioaccumulation of CBZ, even though biosorption of this molecule by the microalgae is possible, it is usually negligible [34].

In addition, to confirm the presence of the transformation products generated by the CBZ transformation by A. braunii, MS analyses were carried out in positive mode electrospray ionization. UHPLC/MS/MS data showed the qualitative presence of three different metabolites in the cell-free supernatants (Table 4), confirming the biotransformation role of $A$. braunii cells on CBZ. The most abundant compound detected was 10-hydroxycarbamazepine (10-OH CBZ). From these results, 10-OH CBZ was the one mostly resembling CBZ; we could be sure that this metabolite is the one that appeared on the HPLC at earlier times at the same wavelength. The other detected metabolites did not appear in the HPLC chromatograms, despite the sensitivity of this analytical method. This suggests that these are unstable and/or are present in concentrations that are below the instrumental limit of detection (LOD) of the used HPLC method.

Based on the chemical structure of the organic intermediates (degradation products), a possible mechanism of the formation of $10-\mathrm{OH}$ CBZ consisting of a two-step reaction could be explained by the epoxidation of carbamazepine, followed by a direct ring-opening of the resulting epoxide and the formation of the resulting alcohol is proposed in Figure 7. 
Table 4. CBZ metabolites detected by ultraperformance liquid chromatography-tandem mass spectrometry (UHPLC/MS/MS).

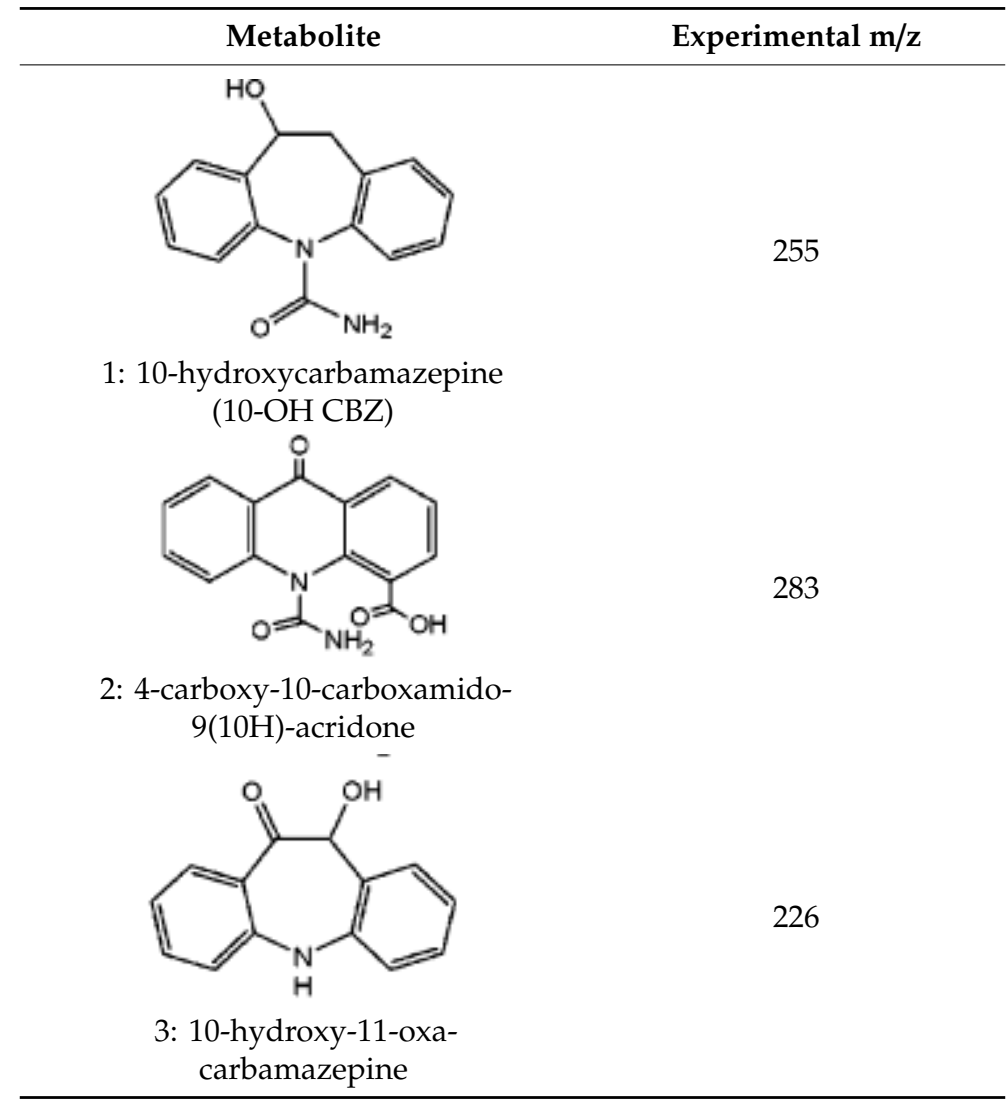

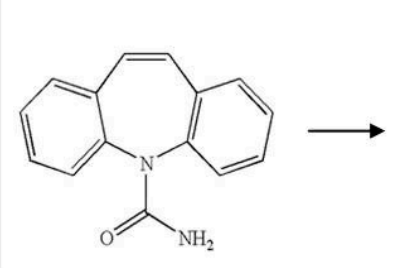

$\mathrm{CBZ}$

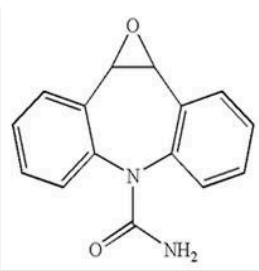

10,11-CBZ Epoxide

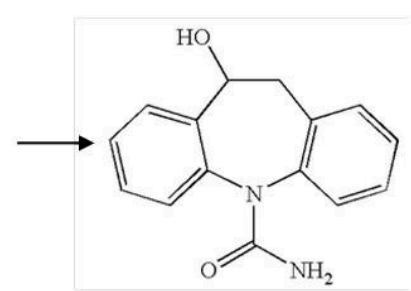

$10-\mathrm{OH} \mathrm{CBZ}$

Figure 7. Proposed oxidation reaction of CBZ by A. braunii and the formation of 10-OH CBZ.

From these data, it can be concluded that in the case of $A$. braunii cells, the major mechanism involved in the elimination of CBZ was bioaccumulation (at about $80 \%$ ). It can be supposed that the other main mechanism of CBZ removal was the biometabolic oxidative transformation of CBZ mainly into 10-OH CBZ.

To the authors' knowledge, this is the first study reporting on the detection CBZ intermediates formed during the CBZ biodegradation by A. braunii. However, more detailed analysis is needed in the future in order to clarify the mechanism of the biotransformation step and to extend the knowledge on the role of $A$. braunii in the elimination of this refractory pharmaceutic compound.

\section{Conclusions}

An original biological treatment for the removal of carbamazepine (CBZ), a highly persistent molecule in wastewater treatment plants, was investigated in this work using the algae Ankistrodesmus braunii (A. braunii). Experimental data demonstrated first that CBZ is efficiently removed; up to $87.6 \%$ CBZ was found to be eliminated at high $A$. braunii concentrations of $10^{5}$ cells $/ \mathrm{mL}$, starting with an initial 
CBZ concentration of $2.5 \mathrm{mg} / \mathrm{L}$. The removal of CBZ was enhanced by increasing the concentration of algae and impaired by initial higher concentrations of CBZ after 60 days. On the contrary, from a kinetic point of view, high CBZ contents and lower inoculum concentrations promoted a more rapid elimination of CBZ, despite the lower final values of the removal yield. This highlights the dual role of $C B Z$ that is a nutritive source for the algae but seems to be toxic at a high dose. An analysis of the fate of CBZ confirmed that about $80 \%$ of the CBZ removed was accumulated in A. braunii cells, but the presence of several metabolites found in the cell-free supernatant and in the cells indicated that biotransformation of CBZ also occurred in parallel: three main metabolites of CBZ have been identified, and the surface area of secondary peaks in HPLC chromatograms was clearly negatively correlated with the peak of CBZ.

Finally, all these results prove that a biological treatment using A. braunii could be more efficient for the removal CBZ from water than many other conventional techniques, either biological or physicochemical. However, treatment time remained long, and its effectiveness depends on other carbon sources. So, further work is still needed to circumvent these drawbacks, first to optimize the parameters of the $A$. braunii growth, and then to investigate the ability of $A$. braunii to remove CBZ in real water in relation to the influence of the culture media used in this work.

Author Contributions: Conceptualization, C.V., T.Y., G.E.B., F.A., and L.F.; formal analysis, N.F., H.B., and L.F.; investigation, T.Y., N.F., and L.F.; methodology, T.Y., H.B., G.E.B., and C.V.; resources, F.A., and L.F.; software, N.F., and F.A.; supervision, C.V., F.A., G.E.B., and L.F.; validation, T.Y., N.F., H.B., F.A., G.E.B., C.V., and L.F.; Writing-Original draft, T.Y., C.V., and L.F. All authors have read and agreed to the published version of the manuscript.

Funding: Part of this work was supported by the project "Excellence, performance and competitiveness in the Research, Development and Innovation activities" at "Dunărea de Jos University of Galati", acronym "EXPERT", financed by the Romanian Ministry of Research and Innovation in the framework of Programme 1-Development of the national research and development system, Sub-programme 1.2-Institutional Performance-Projects for financing excellence in Research, Development and Innovation, Contract No. 14PFE/17.10.2018.

Acknowledgments: L.F. and C.V. are thankful to the Chemical and Process Engineering laboratory for the analytical support in the identification of the biodegradation metabolites.

Conflicts of Interest: The authors declare no conflict of interest.

\section{References}

1. Schwarzenbach, R.P.; Escher, B.I.; Fenner, K.; Hofstetter, T.B.; Jonson, C.A.; von Gunten, U.; Wehrli, B. The challenge of micropollutants in aquatic systems. Science 2006, 313, 1072-1077. [CrossRef] [PubMed]

2. Semrany, S.; Favier, L.; Djelal, H.; Taha, S.; Amrane, A. Bioaugmentation: Possible solution in the treatment of Bio-refractory organic compounds (Bio-ROCs). Biochem. Eng. J. 2012, 69, 75-86. [CrossRef]

3. Yehya, T.; Chafi, M.; Balla, W.; Vial, C.; Essadki, A.; Gourich, B. Experimental analysis and modeling of denitrification using electrocoagulation process. Sep. Purif. Technol. 2014, 132, 644-654. [CrossRef]

4. Doerr-MacEwen, N.A.; Haight, M.E. Expert stakeholders' views on the management of human pharmaceuticals in the environment. Environ. Manag. 2006, 38, 853-866. [CrossRef]

5. Stackelber, P.E.; Furlon, T.E.; Meyer, M.T.; Zaugg, S.D.; Henderson, A.K.; Reissman, D.B. Persistence of pharmaceutical compounds and other organic wastewater contaminants in a conventional drinking-water treatment plant. Sci. Total Environ. 2004, 329, 99-113. [CrossRef]

6. Mudgal, S.; De Toni, A.; Lockwood, S.; Salès, K.; Backhaus, T.; Sorensen, B.H. Study on the Environmental Risks of Medicinal Products, BIO Intelligence Service, Executive Agency for Health and Consumers. 2013. Available online: http://ec.europa.eu/health/files/environment/study_environment.pdf (accessed on 7 November 2020).

7. Mohapatra, D.P.; Brar, S.K.; Tyagi, R.D.; Picard, P.; Surampalli, R.Y. Analysis and advanced oxidation treatment of a persistent pharmaceutical compound in wastewater and wastewater sludge-carbamazepine. Sci. Total Environ. 2014, 470-471, 58-75. [CrossRef]

8. Favier, L.; Simion, A.I.; Rusu, L.; Pacala, M.L.; Grigoras, C.; Bouzaza, A. Removal of an organic refractory compound by photocatalysis in batch reactor-kinetic studies. Environ. Eng. Manag. J. 2015, 14, 1327-1328. [CrossRef] 
9. Thacker, P.D. Pharmaceutical data elude researchers. Environ. Sci. Technol. 2005, 39, 193A-194A.

10. Hai, F.I.; Li, X.; Price, W.E.; Nghiem, L.D. Removal of carbamazepine and sulfamethoxazole by MBR under anoxic and aerobic conditions. Bioresour. Technol. 2011, 102, 10386-10390. [CrossRef]

11. Kosjek, T.; Andersen, H.; Kompare, B.; Ledin, A.; Heath, E. Fate of carbamazepine during water treatment. Environ. Sci. Technol. 2009, 43, 6256-6261. [CrossRef]

12. Yehya, T.; Favier, L.; Kadmi, Y.; Audonnet, F.; Fayad, N.; Gavrilescu, M.; Vial, C. Removal of carbamazepine by electrocoagulation: Investigation of some key operational parameters. Environ. Eng. Manag. J. 2015, 14, 639-645.

13. Miao, X.S.; Yang, J.J.; Metcalfe, C.D. Carbamazepine and its metabolites in wastewater and in biosolids in a municipal wastewater treatment plant. Environ. Sci. Technol. 2005, 39, 7469-7475. [CrossRef] [PubMed]

14. Li, A.; Cai, R.; Cui, D.; Qiu, T.; Pang, C.; Yang, J.; Ma, F.; Ren, N. Characterization and biodegradation kinetics of a new cold-adapted carbamazepine-degrading bacterium, Pseudomonas sp. CBZ-4. J. Environ. Sci. 2013, 25, 2281-2290. [CrossRef]

15. Miao, X.S.; Metcalfe, C.D. Determination of carbamazepine and its metabolites in aqueous samples using liquid chromatography-electrospray tandem mass spectrometry. Anal. Chem. 2003, 75, 3731-3738. [CrossRef] [PubMed]

16. Heberer, T. Occurrence, fate, and removal of pharmaceutical residues in the aquatic environment: A review of recent research data. Toxicol. Lett. 2002, 131, 5-17. [CrossRef]

17. Metcalfe, C.D.; Koenig, B.G.; Bennie, D.T.; Servos, M.; Ternes, T.A.; Hirsch, R. Occurrence of neutral and acidic drugs in the effluents of Canadian sewage treatment plants. Environ. Chem. Lett. 2003, 22, 2872-2880. [CrossRef] [PubMed]

18. Hai, F.I.; Yang, S.; Asif, M.B.; Sencadas, V.; Shawkat, S.; Sanderson-Smith, M.; Gorman, J.; Xu, Z.-Q.; Yamamoto, K. Carbamazepine as a possible anthropogenic marker in water: Occurrences, toxicological effects, regulations and removal by wastewater treatment technologies. Water 2018, 10, 107. [CrossRef]

19. Sipma, J.; Osuna, B.; Collado, N.; Monclus, H.; Ferrero, V.; Comas, J.; Rodriguez-Roda, I. Comparison of removal of pharmaceuticals in MBR and activated sludge systems. Desalination 2010, 250, 653-659. [CrossRef]

20. Popa Ungureanu, C.; Favier, L.; Bahrim, G.; Amrane, A. Response surface optimization of experimental conditions for carbamazepine biodegradation by Streptomyces MIUG 4.89. New Biotechnol. 2015, 32, 347-357. [CrossRef]

21. Zhang, Y.J.; Geissen, S.U.; Gal, C. Carbamazepine and diclofenac: Removal in wastewater treatment plants and occurrence in water bodies. Chemosphere 2008, 73, 1151-1161. [CrossRef]

22. Hata, T.; Shintate, H.; Kawai, S.; Okamura, H.; Nishida, T. Elimination of carbamazepine by repeated treatment with laccase in the presence of 1-hydroxybenzotriazole. J. Hazard Mater. 2010, 181, 1175-1178. [CrossRef] [PubMed]

23. Andreozzi, R.; Marotta, R.; Pinto, G.; Pollio, A. Carbamazepine in water: Persistence in the environment, ozonation treatment and preliminary assessment on algal toxicity. Water Res. 2002, 36, 2869-2877. [CrossRef]

24. Wang, Q.; Liu, W.; Li, X.; Wang, R.; Zhai, J. Carbamazepine toxicity and its co-metabolic removal by the cyanobacteria Spirulina platensis. Sci. Total Environ. 2020, 706, 135686. [CrossRef]

25. Matamoros, V.; Uggtetti, E.; Garcia, J.; Bayona, J.P. Assessment of the mechanisms involved in the removal of emerging contaminants by microalgae from wastewater: A laboratory scale study. J. Hazard Mater. 2016, 301, 197-205. [CrossRef] [PubMed]

26. Xiong, J.-Q.; Kurade, M.B.; Abou-Shanab, R.A.I.; Ji, M.-K.; Choi, J.; Kim, J.O.; Jeon, B.-H. Biodegradation of carbamazepine using freshwater microalgae Chlamydomonas Mexicana and Scenedesmus obliquus and the determination of its metabolic fate. Bioresour. Technol. 2016, 205, 183-190. [CrossRef]

27. García-Galán, M.J.; Arashiro, L.; Santos, L.H.M.L.M.; Insa, S.; Rodríguez-Mozaz, S.; Barceló, D.; Ferrer, I.; Garfí, M. Fate of priority pharmaceuticals and their main metabolites and transformation products in microalgae-based wastewater treatment systems. J. Hazard Mater. 2020, 390, 121771. [CrossRef]

28. De Wilt, A.; Butkovskyi, A.; Tuantet, K.; Hernandez Leal, L.; Fernandes, T.V.; Langenhoff, A.; Zeeman, G. Micropollutant removal in an algal treatment system fed with source separated wastewater streams. J. Hazard Mater. 2016, 304, 84-92. [CrossRef]

29. Deegan, A.M.; Shaik, B.; Nolan, K.; Urell, K.; Oelgemöller, M.; Tobin, J.; Morrissey, A. Treatment options for wastewater effluents from pharmaceutical companies. Int. J. Environ. Sci. Technol. 2011, 8, 649-666. [CrossRef] 
30. Hua, W.Y.; Bennett, E.R.; Letcher, R.J. Ozone treatment and the depletion of detectable pharmaceuticals and atrazine herbicide in drinking water sourced from the upper Detroit River, Ontario, Canada. Water Res. 2006, 40, 2259-2266. [CrossRef]

31. Mohapatra, D.P.; Brar, S.K.; Tyagi, R.D.; Picard, P.; Surampalli, R.Y. A comparative study of ultrasonication, Fenton's oxidation and ferro-sonication treatment for degradation of CBZ from wastewater and toxicity test by Yeast Estrogen Screen (YES) assay. Sci. Total Environ. 2013, 447, 280-285. [CrossRef]

32. Doll, T.; Frimmel, F. Cross-flow microfiltration with periodical back-washing for photocatalytic degradation of pharmaceutical and diagnostic residues-evaluation of the long-term stability of the photocatalytic activity of $\mathrm{TiO}_{2}$. Water Res. 2005, 39, 847-854. [CrossRef] [PubMed]

33. Shu, Z.; Bolton, J.R.; Belosevic, M.; El Din, J.M. Photodegradation of emerging micropollutants using the medium-pressure UV/ $\mathrm{H}_{2} \mathrm{O}_{2}$ Advanced Oxidation Process. Water Res. 2013, 47, 2881-2889. [CrossRef] [PubMed]

34. Xiong, J.-Q.; Kurade, M.B.; Jeon, B.-H. Can Microalgae Remove Pharmaceutical Contaminants from Water? Trends Biotechnol. 2018, 36, 30-44. [CrossRef] [PubMed]

35. Chong, M.N.; Jin, B. Photocatalytic treatment of high concentration carbamazepine in synthetic hospital wastewater. J. Hazard Mater. 2012, 199-200, 135-142. [CrossRef]

36. Truhaut, R.; Ferard, J.F.; Jouany, J.M. Cadmium IC50 determinations on Chlorella vulgaris involving different parameters. Ecotoxicol. Environ. Saf. 1980, 4, 215-223. [CrossRef]

37. Iqbal, M.; Grey, D.; Sepan-Sarkissian, G.; Fowler, M.W. Interactions between the unicellular red alga Porphyridiumcruentum and associated bacteria. Eur. J. Phycol. 1993, 28, 63-68. [CrossRef]

38. Fortuna, A.; Alves, G.; Soares-da-Silva, P.; Falcão, A. Pharmacokinetics, brain distribution and plasma protein binding of carbamazepine and nine derivatives: New set of data for predictive ADME models. Epilepsy Res. 2013, 107, 37-50. [CrossRef] [PubMed]

39. Saéz, P.B.; Rittmann, B.E. Biodegradation kinetics of a mixture containing a primary substrate (phenol) and an inhibitory co-metabolite (4-chlorophenol). Biodegradation 1993, 4, 3-21. [CrossRef] [PubMed]

40. Gauthier, H.; Yargeau, V.; Cooper, D.G. Biodegradation of pharmaceuticals by Rhodococcus rhodochrous and Aspergillus niger by co-metabolism. Sci. Total Environ. 2010, 408, 1701-1706. [CrossRef]

41. Popa, C.; Favier, L.; Dinica, R.; Semrany, S.; Djelal, H.; Amrane, A.; Bahrim, G. Potential of newly wild Streptomyces stains as agents for the biodegradation of a recalcitrant pharmaceutical, carbamazepine. Environ. Technol. 2014, 35, 3082-3091. [CrossRef] [PubMed]

42. Ziagova, M.; Kyriakou, G.; Liakopoulou-Kyriakides, M. Co-metabolism of 2,4 dichlorophenol and 4-Cl-m-cresol in the presence of glucose as an easily assimilated carbon source by Staphylococcus xylosus. J. Hazard Mater. 2009, 163, 383-390. [CrossRef] [PubMed]

43. Todd, S.J.; Cain, R.B.; Schmidt, S. Biotransformation of naphthalene and diaryl ethers by green microalgae. Biodegradation 2002, 12, 229-238. [CrossRef] [PubMed]

44. Pollio, A.; Pinto, G.; Della Greca, M.; De Maio, A.; Fiorentino, A.; Previtera, L. Progesterone bioconversion by microalgal cultures. Phytochemistry 1994, 37, 1269-1272. [CrossRef]

45. Pinto, G.; Pollio, A.; Previtera, L.; Stanzione, M.; Temussi, F. Removal of low-molecular weight phenols from olive oil mill wastewater using microalgae. Biotechol. Lett. 2003, 25, 1657-1659. [CrossRef] [PubMed]

46. Della Greca, M.; Pinto, G.; Pollio, A.; Previtera, L.; Temussi, F. Biotransformation of sinapic acid by the green algae Stichococcus bacillaris 155LTAP and Ankistrodesmus braunii C202.7a. Tetrahedron Lett. 2003, 44, 2779-2780. [CrossRef]

47. Vidotti, A.D.S.; Riaño-Pachón, D.M.; Mattiello, L.; Albuquerque Giraldia, L.; Winck, F.V.; Franco, T.T. Analysis of autotrophic, mixotrophic and heterotrophic phenotypes in the microalgae Chlorella vulgaris using time-resolved proteomics and transcriptomics approaches. Algal Res. 2020, 51, 102060. [CrossRef]

48. Larcher, S.; Yargeau, V. Biodegradation of $17 \alpha$-ethinylestradiol by heterotrophic bacteria. Environ. Pollut. 2013, 173, 17-22. [CrossRef]

49. Popa Ungureanu, C.; Favier, L.; Bahrim, G. Screening of soil bacteria as potential agents for drugs biodegradation: A case study with clofibric acid. J. Chem. Technol. Biotechnol. 2016, 91, 1646-1653. [CrossRef]

50. Hemidouche, S.; Favier, L.; Amrane, A.; Dabert, P.; Le Roux, S.; Sadaoui, Z. Successful Biodegradation of a Refractory Pharmaceutical Compound by an Indigenous Phenol-Tolerant Pseudomonas aeruginosa Strain. Water Air Soil Pollut. 2018, 229, 103. [CrossRef] 
51. Ungureanu, C.V.; Favier, L.; Bahrim, G.E. Improving Biodegradation of Clofibric Acid by Trametes pubescens through the Design of Experimental Tools. Microorganisms 2020, 8, 1243. [CrossRef]

52. Larsson, D.G.; de Pedro, C.; Paxeus, N. Effluent from drug manufactures contains extremely high levels of pharmaceuticals. J. Hazard Mater. 2007, 148, 751-755. [CrossRef] [PubMed]

53. Marco-Urrea, E.; Pérez-Trujillo, M.; Vincent, T.; Caminal, G. Ability of white-rot fungi to remove selected pharmaceuticals and identification of degradation products of ibuprofen by Trametes versicolor. Chemosphere 2009, 74, 765-772. [CrossRef] [PubMed]

54. Oppenheimer, J.; Stephenson, R.; Burbano, A.; Liu, L. Characterizing the passage of personal care products through the wastewater treatment process. Water Environ. Res. 2007, 79, 2564-2577. [CrossRef] [PubMed]

55. Stackelberg, P.E.; Gibs, J.; Furlong, E.T.; Meyer, M.T.; Zaugg, D.; Lippincott, R.L. Efficiency of the conventional drinking-water-treatment process in the removal of pharmaceuticals and other organic compounds. Sci. Total Environ. 2007, 377, 255-272. [CrossRef]

56. Dotto, G.L.; Cadaval, T.R.S.; Pinto, L.A.A. Use of Spirulina platensis micro and nanoparticles for the removal synthetic dyes from aqueous solutions by biosorption. Process Biochem. 2012, 9, 1335-1343. [CrossRef]

57. Denizli, A.; Cihangir, N.; Rad, A.Y.; Taner, M.; Alsancak, G. Removal of chlorophenols from synthetic solutions using Phanerochaete chrysosporium. Process Biochem. 2004, 12, 2025-2030. [CrossRef]

58. Blánquez, P.; Casas, N.; Font, X.; Gabarell, X.; Sarrà, M.; Caminal, G.; Vincent, T. Mechanism of textile metal dye biotransformation by Trametes versicolor. Water Res. 2004, 38, 2166-2172. [CrossRef]

Publisher's Note: MDPI stays neutral with regard to jurisdictional claims in published maps and institutional affiliations. 